\title{
Nilai-Nilai Pendidikan Akidah dalam Novel "Mars Betapa Berartinya Sosok Ibu Dalam Hidupku” Karya Aishworo Ang
}

\author{
Ida Aroyani \\ Institut Agama Islam Darussalam (IAID), Ciamis-Jawa Barat \\ Email: ida.aroyani2017@gmail.com \\ Hasanudin \\ Institut Agama Islam Darussalam (IAID), Ciamis-Jawa Barat \\ Husni \\ Institut Agama Islam Darussalam (IAID), Ciamis-Jawa Barat
}

\begin{abstract}
This study aims to 1) determine the values of Akidah Education in "Novel MARS How Meaningful a Mother in My Life" by Aishworo Ang. 2) find out the relevance of Akidah Education Values in the novel "MARS How Meaningful a Mother is in My Life" by Aishworo Ang with current Islamic education. The research method used by the author is content analysis. This analysis is used by the writer to reveal, understand and capture literary works. Meanwhile, data collection techniques are literature study techniques or documentation by examining various writings related to the object of research. The collected data were then analyzed using the stages of data processing, categorization, and data interpretation. After analyzing the data, the authors obtained the following conclusions: 1) The values of akidah education in the novel "MARS How Meaningful a Mother's Figure in My Life" by Aishworo Ang includes: a) Illahiyat, (a matter of divinity such as about His Essence) b ) Nubuwat, (prophetic issues, scriptures, etc.) c) Ruhaniyat (unseen problems such as spirits, angels, jinn, etc.) d) Sam'iyyat, (problems that can be known through revelation, such as barzhakh, heaven, hell and others) 2) The Relevance of Akidah Educational Values in Aishworo Ang's Novel "MARS How Meaningful a Mother's Figure is in My Life" with current Islamic education, which is in accordance with the aims of education aimed at improving the quality of Indonesian people, namely humans having faith and fearing God Almighty, this is in line with the contents of the story in the novel "MARS How Meaningful a Mother's Figure in My Life" which generally contains the values of faith, including faith in Alla. $h$, faith in the book of Allah, faith in the Angel of God, faith in the Prophet, faith in the Last Day, and faith in the destiny of Allah.
\end{abstract}

Keywords: Akidah Educational Values, Novel 


\section{PENDAHULUAN}

Kemunduran umat dari tujuan hidupnya yang terbesar adalah karena kelemahan akidah (Sabiq, 1995: 28). Akidah bisa menjadi goyah dan iman di dalam hati menjadi rapuh karena akidah dalam diri seseorang sudah tidak lagi berpengaruh terhadap perilaku individu dan iman tidak lagi memiliki kekuasaan terhadap amal perbuatan manusia. Kelemahan akidah ini menyebabkan ketidakberdayaan umat dalam mencapai tujuan akhir yakni mencapai puncak kekuatan dan meraih batas optimal yang keyakinannya dapat mendorong untuk meraih kemuliaan hidup dan mengangkat ke puncak kejayaan dan kehormatan (Sabiq, 2010: 15-16).

Yusuf Qardlawi dalam Muhammad Chirzin menyatakan bahwa iman adalah kepercayaan yang meresap ke dalam hati dengan penuh keyakinan, tidak bercampur syak dan ragu, serta memberi pengaruh bagi pandangan hidup, tingkah laku dan perbuatan pemiliknya seharihari. Pada hakekatnya, iman atau akidah adalah keseluruhan tingkah laku, sehingga setiap perilaku yang tidak disertai dengan dan tidak dikaitkan kepada keimanan dinyatakan hampa, kosong tidak berbobot dan tidak mengandung arti apa-apa. Penanaman nilai akidah tidak hanya diperoleh dari pendidikan formal maupun non formal. Namun seiring perkembangan ilmu pengetahuan dan teknologi, pendidikan dapat dilaksanakan melalui media pendidikan lain, baik media massa, cetak maupun media elektronik. Dari media elektronik mencakup visual dan audiovisual, media penyiaran surat kabar, novel, film dan berbentuk komunikasi lain yang menciptakan sarana berfikir kepada masyarakat , dari berbagai macam sarana media pendidikan, biarlah masyarakat yang menentukan sendiri media pendidikan mana yang mereka pilih (Rohmat, 2016: 43).

Pendidikan akidah memiliki andil yang sangat besar dan penting di dalam kehidupan, karena akidah merupakan pokok utama dalam ajaran Islam. Akidah Islam akan melahirkan seseorang atau masyarakat yang mempunyai kepribdian yang unggul yang akhirnya akan diaplikasikan melalui tingkah laku, percakapan dan gerak-gerik hati seseorang atau suatu masyarakat. Akidah Islam yang telah meresap ke dalam jiwa dan lubuk hati seseorang akan menimbulkan kesan-kesan positif. Namun memandang perkembangan dunia saat ini dengan sangat terbukanya persilangan budaya, akan berdampak pada bergesernya nilai suatu bangsa. Pergeseran ini dapat berdampak pada menurunya nilai-nilai keimanan di masyarakat dan juga peserta didik. Merajalelanya kriminalitas dari mulai minuman keras, seks bebas, narkoba, kekerasan, sampai pembunuhan. Hal ini diakibatkan karena menipisnya nilai-nilai keimanan dalam hati mereka. Maka dari itu, sangat dibutuhkan peran pendidikan akidah untuk menanamkan nilainilai keimanan dalam diri masyarakat dan juga peserta didik.

Dalam kehidupan suatu bangsa pendidikan mempunyai peranan yang sangat penting, yaitu untuk menjamin perkembangan dan 


\section{BESTARI}

Vol. 18, No. 1, 2021

p-ISSN 1907-1337; e-ISSN 2807-6532

kelangsungan kehidupan suatu bangsa, sehingga dapat diartikan bahwa maju mundurnya suatu bangsa sebagian besar ditentukan oleh maju mundurnya pendidikan di negara tersebut, karena bagaimanapun juga, pendidikan merupakan wahana untuk mencetak sumber daya manusia (SDM) yng berkualitas, serta perlu diketahui bahwa pendidikan jauh lebih dahulu adanya dibandingkan dengan munculnya negara (Tafsir, 2007: 75).

\section{KAJIAN TEORI}

\section{Konsep Nilai}

Nilai adalah standar tingkah laku, keindahan, keadilan, dan efisiensi yang mengikat manusia dan sepatutnya dijalankan serta dipertahankan. Nilai adalah bagian dari potensi manusiawi seseorang, yang berada dalam rohaniah (batiniah, spiritual), tidak berwujud, tidak dapat dilihat, tidak dapat diraba,dan sebagainya, akan tetapi pengaruhnya sangat kuat dan peranannya penting dalam setiap perbuatan dan penampilan seseorang (Zakiyah dan Rasdiana, 2014: 147).

Menurut Ahmadi dan Salimi (1994: 202), nilai adalah seperangkat keyakinan atau perasaan yang diyakini sebagai suatu identitas yang memberikan corak yang khusus pada pola pemikiran, perasaan, keterkaitan maupun perilaku. Demikian juga Ang Ridwan (2013: 244) mengatakan bahwa nilai merupakan daya motivasi yang penting karena relevan dengan banyak aspek dari perilaku seseorang yang sekali terbina cenderung akan berlangsung relatif abadi.

Jadi dari beberapa pengertian di atas dapat disimpulkan bahwa nilai yang dimaksud disini adalah sesuatu yang diyakini kebenarannya yang bermanfaat dan berguna bagi manusia sebagai acuan atau tolak ukur tingkah laku.

\section{Konsep Pendidikan Akidah}

Pendidikan dalam pengertian Bahasa disebut: the process of training and developing the knowledge, skills, mind, character,etc. (proses melatih dan mengembangkan pengetahuan, keterampilan, pikiran, perilaku, dan lain-lain (Qodri, 2002: 18). Pada hakekatnya, pendidikan merupakan proses pembentukan akhlak moral dan bukan hanya proses belajar mengajar yang dibatasi oleh tempat dinding dan meja kursi yang tertata rapi, tetapi proses dimana manusia sadar menangkap, menyerap dan menghayati peristiwa alam sepanjang zaman. Selain itu juga pendidikan yang ideal adalah sistem belajar yang memberikan ruang kreativitas seluasnya kepada anak didik. Dalam proses belajar siswa diarahkan untuk menyampaikan pemikirannya, dan tidak sekedar hanya menuruti atau menghafal materi belajar.

Pendidikan menurut al-Ghazali dalam Rusn (2009: 56) yaitu proses memanusiakan manusia sejak masa kejadiannya sampai akhir 
hayatnya melalui berbagai ilmu pengetahuan yang disampaikan dalam bentuk pengajaran secara bertahap, di mana proses pengajaran itu menjadi tanggung jawab orang tua dan masyarakat menuju pendekatan diri kepada Allah sehingga menjadi manusia sempurna.

Pendidikan adalah usaha sadar yang dilakukan manusia lain atau memindahkan nilai norma yang dimilikinya kepada orang lain dalam masyarakat (Ali, 1998:179). Pendidikan sebagai usaha membina dan mengembangkan pribadi manusia; aspek rohaniah dan jasmaniah, juga harus berlangsung secara bertahap, oleh karena itu suatu kematangan yang bertitik akhir pada optimalisasi perkembangan/pertumbuhan, baru dapat tercapai bilamana berlangsung melalui proses demi proses ke arah tujuan akhir perkembangan/pertumbuhan (Arifin, 2005: 12).

John Dewey dalam Muzayyin Arifin (2005: 33) pernah menyatakan bahwa: Education is the process without end," Pendidikan itu adalah suatu proses tanpa akhir". Sejalan dengan strategi pendidikan yang secara universal ditetapkan perserikatan Bangsa-Bangsa sebagai Life long education "Pendidikan sepanjang hayat". Dengan demikan tugas dan fungsi pendidikan berlangsung secara continu dan berkesinambungan bagaikan spiral yang sambung menyambung dari satu jenjang ke jenjang lain yang bersifat progresif mengikuti kebutuhan manusia dalam bermasyarakat secara luas.

Akidah berasal dari kata "aqada" artinya ikatan dua utas tali dalam satu buhul sehingga bersambung, akidah menurut terminologi adalah sesuatu yang mengharuskan hati membenarkannya, membuat jiwa tenang, dan menjadi kepercayaan yang bersih dari kebimbangan dan keraguan (Suryana, dkk, tt: 94).

Akidah secara istilah berarti sejumlah kebenaran yang dapat diterima secara umum oleh manusia berdasarkan fitrah, akal dan wahyu, kemudian dipatrikan dalam hati, diyakini keshahihannya (kebenarannya) dan ditolak kebenaran selainnya (Syafe'i, dkk, 2014: 97). Dalam ajaran agama Islam, Akidah merupakan keyakinan atas sesuatu yang terdapat dalam apa yang disebut dengan rukun iman, yaitu keyakinan kepada Allah, Malaikat-Nya, kitab-kitab-Nya, rasul-rasulNya, hari akhirat, serta takdir baik dan buruk.

Untuk itu Allah SWT memerintahkan semua umat manusia agar menggunakan akal pikirannya dengan sebaik-baiknya, dan memperhatikan serta merenungkan segala ciptaan-Nya. Salah satu cara untuk berma'rifat (mengetahui), mengenal, dan meng-Imani sifat-sifat dan kekuasaan Allah SWT ialah dengan memperhatikan segala makhluk ciptaan-Nya (Thoha, dkk, 2004: 88).

Gustave Le Bon seorang pujangga Prancis yang terkenal dan seorang ahli kemasyarakatan dan kitabnya Al-Araa'wal Mu'taqadat seperti dikutip oleh Ash-Shiddieqy mentakrifkan bahwa akidah itu, ialah keimanan yang tumbuh dari suatu sumber yang tak dapat dirasakan yang memaksa manusia mempercayai suatu ketentuan tanpa dalil. Akidah itu merupakan ilham yang tumbuh dengan sendirinya yang 


\section{BESTARI}

Vol. 18, No. 1, 2021

p-ISSN 1907-1337; e-ISSN 2807-6532

tak dapat dirasakan, tumbuh dari sebab-sebab yang terlepas dari pengaruh kemauan (Ash-Shiddieqy, 2009: 32-33).

Akidah sebagai fondamen utama ajaran Islam bersumber pada Alquran dan Sunah Rasul, dalam hal yang berkaitan dengan keyakinan tidak seluruhnya dapat ditemukan oleh kemampuan yang dimiliki oleh manusia, misalnya, manusia dapat memikirkan alam raya yang begitu teratur dan seimbang, tetapi manusia tidak dapat mengetahui siapa yang mengatur dan menciptakannya, karena kemampuan akalnya sangat terbatas, karena itu untuk dapat mengetahuinya dibutuhkan informasi, disini wahyu memberi tahu bahwa yang menciptakan alam raya ini adalah Allah. Demikian halnya, manusia mengetahui bahwa dalam kehidupan dunia ini, yang baik tidak selalu beruntung, dan yang jahat tidak selalu mendapat hukuman (Suryana, dkk, tt: 95-96).

Pendidikan akidah merupakan pendidikan yang sangat penting di dalam kehidupan kita. hal itu dikarenakan akidah merupakan sebuah ajaran tentang keimanan terhadap ke-Esaan Allah swt (Ahmadi dan Salimi, 1994: 98). Kedudukannya yang sangat sentral dan fundamental yang mejadi titik tolak kegiatan seorang muslim, yang mana akidah Islam ini berawal dari keyakinan kepada Dzat Mutlak Yang Maha Esa Yang disebut Allah. Allah Yang Maha Esa dalam Dzat, sifat, perbuatan dan wujud-Nya itu disebut dengan tauhid (Ali, 1998: 199).

Berdasarkan pengertian di atas, akidah adalah pengajaran dan pembimbingan terhadap peserta didik agar memiliki akidah yang baik dan benar serta keyakinan yang kuat sesuai dengan ajaran Islam. Pengajaran tersebut tidak hanya dengan lisan akan tetapi bisa juga dengan perilaku atau tingkah laku. Nilai-nilai pendidikan akidah adalah sifat-sifat yang melekat pada pendidikan akidah yang digunakan sebagai pedoman hidup dimana ajaran Islam ditegakkan.

Begitu pentingnya akidah ini sehingga Nabi Muhammad SAW penutup para nabi dan rasul, membimbing umatnya selama 13 tahun ketika berada di Mekah dengan menekankan masalah akidah. sebab akidah adalah landasan semua tindakan, bahkan merupakan landasan bangunan Islam. Oleh karena itu, para dai dan para pelurus agama dalam setiap masa lalu memulai dakwah mereka dengan tauhid dan pelurusan akidah (Mukni'ah, 2011: 50). Menurut Syafe'i dkk (2014: 97) menyatakan beberapa nilai-nilai pendidikan akidah di antaranya:

a. Illahiyat (masalah ketuhanan seperti tentang Dzat-Nya)

Nilai Illahiyat adalah nilai-nilai yang membahas tentang segala sesuatu yang berhubungan dengan Ilah (Allah), seperti wujud Allah, sifat-sifat Allah, nama-nama Allah af'al Allah dan lain-lain. Keyakinan yang valid mengenai allah berarti beriman kepada-Nya dan membenarkan bahwa Dia Maha Ada, Maha Pencipta, Maha Pemberi Rezeki, Yang menghidupkan dan Yang mematikan, bagi-Nya hak menciptakan dan memerintah dan kepada-Nya tempat kembali, 
beriman kepada Zat-Nya, sifat-sifat-Nya dan asma-asma-Nya (Mahmud, 2003: 90).

Beriman kepada Allah serta iman kepada sifat-sifat-Nya akan menandai perilaku seorang muslim, keyakinan yang ada pada dirinya akan dibuktikan pada dampak perilakunya. Jika seseorang telah beriman bahwa Allah itu ada, Maha Melihat dan Maha Mendengar, maka dalam perilaku orang itu akan lahir sikap hati-hati dan waspada. Ia tidak akan merasa sendirian, sekalipun tidak ada orang lain di sekitarnya, sebab ia yakin bahwa Allah itu ada. (Suryana dkk, tt: 98).

b. Nubuwat (masalah kenabian, kitab suci, dan lain-lain)

Nilai Nubuwat adalah nilai-nilai yang membahas tentang segala sesuatu yang berhubungan dengan Nabi dan Rasul, termasuk pembahasan tentang kitab-kitab Allah, Mukjizat, keramat dan lain sebagainya. Ada beberapa indikator bahwa orang tersebut memiliki akidah nubuwat, yaitu:

1) Meyakini bahwa ada manusia utusan Allah yang disebut nabi dan rasul

2) Meyakini kebenaran yang dibawa rasul

3) Meneladani sifat dan perilaku rasul dan nabi

4) Selalu mengambil hikmah dari setiap kisah para nabi dan rasul atau menjadikan para nabi dan rasul sebagai uswatun hasanah

5) Meyakii bahwa Allah menurunkan kitab-kitab sebagai mukjizat yang diberikan Allah kepada nabi-Nya

6) Meyakini bahwa al-Qur'an mukjizat nabi Muhammad

7) Mempelajari dan mengamalkan isi kandungan al-Qur'an.

c. Ruhaniyat (masalah ghaib seperti ruh, malaikat, jin dan lain-lain)

Nilai ruhaniyat yaitu nilai-nilai yang membahas tentang segala sesuatu yang berhubungan dengan alam metafisik seperti malaikat, jin, iblis, setan, ruh dan lain sebagainya. Seseorang akan menunjukan perilaku yang mengindikasikan dari rasa keimanannya itu sendiri. Di antara tanda-tandanya yaitu :

1) Meyakini sepenuh hati keberadaan malaikat, jin, setan,ruh

2) Bertindak hati-hati dalam berperilaku keseharian

3) Selalu berusaha untuk memperbaiki diri sendiri dari waktu ke waktu

4) Berfikir positif terhadap berbagai kejadian

d. Sam’iyyat (masalah-masalah yang bisa diketahui melalui wahyu, seperti barzakh, surga, neraka dan lain-lain)

Sam'iyyat yaitu pembahasan tentang segala sesuatu yang hanya bisa diketahui lewat sam’i (dalil naqli berupa al-Qur'an dan Sunnah) seperti alam barzah, akhirat, azab kubur, tanda-tanda kiamat, dan lain sebagainya (Ilyas, 2009: 6). Seseorang bisa dikatakan memiliki akidah sam’iyat apabila memiliki tanda-tanda di antaranya:

1) Meyakini tentang segala sesuatu tentang ketuhanan Allah

2) Melakukan ikhtiar yang terbaik

3) Bertawakal kepada Allah SWT 


\section{BESTARI}

Vol. 18, No. 1, 2021

p-ISSN 1907-1337; e-ISSN 2807-6532

4) Sangat menyadari dan meyakini bahwa hidup di dunia hanya sesaat dan di akhirat selama-lamanya

5) Selalu melakukan dan meningkatkan amal kebaikan

6) Tetap istiqamah di dalam ketaatan walau dalam keadaan apapun juga

7) Selalu memiliki pengharapan yang baik

8) Ikhlas serta benar-benar mengharapkan ridha Allah SWT.

Jadi yang termasuk ke dalam nilai pendidikan akidah adalah

Illahiyat (ketuhanan), nubuwat (kenabian), ruhaniyat (kerohanian), dan sam’iyyat. Dan berdasarkan pemaparan nilai-nilai akidah, berikut ini penjelasan dari empat materi di atas :

1. Iman kepada Allah

Arti iman iman berasal dari kata amuna/amana/ amina yang mengandung arti jujur, setia, percaya, aman dan tenteram. Iman berarti kejujuran, kepercayaan, keamanan dan ketentuan. Keimanan kepada AllAh berarti kepercayaan akan adanya Allah yang dibenarkan oleh hati, diucapkan dengan lisan dan dibuktikan dengan amal perbuatan dan dengan keimanan itu jiwa menjadi tenang dan tenteram. Beriman kepada Allah SWT. Hakikatnya tidak sekedar atau sebatas membenarkan adanya Allah saja, melainkan juga haruslah dibuktikan dengan ucapan dan perbuatannya. Yakni mengucapkan dengan dua kalimat syahadat dan perbuatannya mengikuti tuntunan Allah dan Rasulullah. Oleh karena itu seseorang pada hakikatnya belum dikatakan beriman kepada Allah jika ucapan dan perbuatannya belum sesuai dengan tuntunan-Nya (Syafe'i, dkk, 2014: 98-99).

Mengenal Allah SWT dapat ditempuh melalui dua jalur. Pertama, dengan menggunakan akal pikiran untuk memeriksa dan memikirkan secara teliti apa yang diciptakan Allah. Kedua, dengan mengerti namanama dan sifat-sifat-Nya dalam Al-Qur'an (Chirzin, 2004: 23).

2. Iman kepada Malaikat

Malaikat jamak dari mal-aka/malak, yang berasal dari la$a k a$ yang secara bahasa mengandung arti menyampaikan, membawa risalah. Memang tugas malaikat adalah membawa perintah Allah untuk disampaikan kepada para makhluk-Nya di bumi hidupnya senantiasa bersujud kepada Allah dan menjalankan perintahnya sedangkan malaikat itu diciptakan dari cahaya oleh karenanya ia bersifat Ghaib (non-fisik) (Syafe'i, dkk, 2014: 102). "Malaikat-malaikat dan Jibril naik (menghadap) kepada Tuhan dalam sehari yang kadarnya limapuluh ribu tahun”. (Q.S. Al-Ma'arij,70: 4).

Beriman kepada Malaikat, ialah percaya bahwa Allah itu mempunyai makhluk yang dinamai "Malaikat" yang tidak pernah durhaka kepada-Nya dan senantiasa taat menjalankan tugas yang dibebankan dengan sebaik-baiknya (Zuhdi, 1993: 25). Orang mukmin percaya sepenuhnya adanya Malaikat di alam ruh, mereka selalu menyertai manusia dan mencatat amal-amalnya, termasuk segala 
kebaikan dan keburukan kita, mereka bertindak benar dan jujur tidak kenal suap ataupun sogok (Chirzin, 2004: 69).

Beriman kepada Allah mestilah beriman juga kepada para malaikat-nya. Dengan beriman kepada para malaikat-Nya maka yakinlah bahwa segala urusan yang menjadi hak manusia pasti akan sampai kepada mereka karena para malaikat tidak pernah ingkar kepada Allah. Termasuk urusan wahyu yang dibawa malaikat Jibril kepada para nabi dan rasul Allah. Selain itu manusia akan berhati-hati dalam hidupnya karena segala gerak-geriknya tidak akan lepas dari pengawasan Allah dan catatan malaikat-Nya (Syafe'I, dkk, 2014: 102). "(yaitu) ketika dua orang malaikat mencatat amal perbuatannya, seorang duduk di sebelah kanan dan yang lain duduk di sebelah kiri”. (Q.S. Qaf, 50: 17).

Iman kepada Malaikat ialah Malaikat itu utusan Allah kepada nabi-nabi-Nya, meyakini bahwa di antara mereka ada yang ditugaskan sebagai utusan-utusan kepada manusia yang dikehendaki-Nya dan ada yang diutus kepada sesamanya dan bahwa mereka memiliki tugas-tugas yang telah ditetapkan oleh Allah (Adam, tt: 39).

3. Iman kepada Kitab

Beriman kepada Kitab-kitab Allah adalah percaya bahwa Allah telah menurunkan beberapa kitab-Nya kepada beberapa Rasul-Nya untuk menjadi pegangan dan pedoman hidupnya guna mencapai kebehagiaan hidup di dunia dan di akhirat (Zuhdi, 1993: 43). Allah menurunkan ajaran-ajaran kepada para Rasul untuk setiap bangsa dan umat manusia sepanjang sejarah, di antara ajaran-ajaran-Nya itu ada yang dicatat dalam kitab dan ada yang tidak dapat diketahui sama sekali, yang pasti setiap Rasul menerima risalah atau pelajaran yang disampaikan kepada umatnya (Chirzin, 2004: 71).

Dengan beriman kepada kitab-kitab Allah, kita dapat memiliki keyakinan yang kuat akan kebenaran terhadap jalan yang kita tempuh. Jalan yang harus kita tempuh tersebut sudah tercantum dalam kitabkitab Allah, untuk umat-umat pada masanya. Dengan demikian, oleh karena kita tidak tahu kemana arah jalan yang akan kita tempuh, baik ketika kita berada didunia, maupun setelah kita tidak ada lagi berada di dunia, dengan anne-marie yakini akan kitab Allah, kita akan mendapatkan gambaran apa yang harus kita lakukan untuk bisa mengikuti jalan yang diminta oleh Allah untuk kita ikuti. Setiap perilaku yang boleh dan tidak boleh kita lakukan, semua terdapat dalam kitab yang diturunkan oleh Allah kepada Nabi dan Rasul. Dengan mengimani kepada kitab Allah, kita akan tahu mana yang boleh dilakukan dan mana yang tidak, dengan begitu, kita akan selalu hidup dalam jalan yang lurus yang telah digariskan oleh Allah untuk kita jalankan (Mukniah, 2011: $72)$.

4. Iman kepada Nabi dan Rasul

Rasul berasal dari kata rasala yang mengandung arti mengutus. Rasul berarti orang yang diutus. Rasul-rasul Allah adalah manusia- 


\section{BESTARI}

Vol. 18, No. 1, 2021

p-ISSN 1907-1337; e-ISSN 2807-6532

manusia pilihan yang diutus oleh Allah untuk menyampaikan wahyu kepada umat manusia sebagai pedoman hidup bagi mereka dalam kehidupan sehari-hari. Jumlah Rasul-rasul yang diutus oleh Allah cukup banyak ada yang diceritakan oleh Allah dan ada yang tidak diceritakan. Sebagaimana firman Allah "Dan (Kami telah mengutus) rasul-rasul yang sungguh telah Kami kisahkan tentang mereka kepadamu dahulu, dan rasul-rasul yang tidak Kami kisahkan tentang mereka kepadamu. Dan Allah telah berbicara kepada Musa dengan langsung" (Q.S. An-Nisa, 4: 164).

Para nabi dan rasul yang diceritakan dalam Al-Qur'an ada 25 orang. Tujuan mereka diutus oleh Allah adalah mengajak manusia untuk beribadah (taat) hanya kepada Allah dan menjauhi thaghut (Syafe'I, dkk, 2014: 103).

Iman kepada Rasul ialah percaya bahwa Allah telah memilih di antara manusia, beberapa orang yang bertindak sebagai utusan Allah, mereka bertugas menyampaikan kepada umat manusia segala wahyu yang diterima dari Allah melalui Malaikat Jibril, dan menunjukan kepada mereka jalan yang lurus, serta membimbing mereka dalam mencapai kesejahteraan dan kebahagiaan hidup di dunia dan di akhirat (Zuhdi, 1993: 63).

kita juga harus meyakini bahwa para rasul dan nabi mendapat petunjuk dan mukjizat dari Allah guna mengatasi orang yang menentangnya. Para rasul dan nabi juga merupakan manusia-manusia yang memiliki pribadi yang mulia, terpelihara dari perbuatan maksiat, pikiran yang tajam, perkataan yang mengandung hikmah, dan pelajaran yang sangat berharga sebagai pandangan hidup manusia. Mereka juga tidak dapat dipengaruhi oleh setan, kekuatan sihir, iblis dan lain sebagainya (Mukni'ah, 2011: 74).

5. Iman kepada Hari Akhir

Hari akhir adalah hari semua kehidupan di dunia ini berakhir, hari alam semesta ini hancur dengan dahsyatnya. Kemudian Allah SWT. Menciptakan kehidupan yang baru, yaitu kehidupan akhirat. Manusia dibangkitkan kembali di hari akhirat dan memasuki kehidupan abadi yang tiada akhir. Tegasnya hari akhir/kiamat adalah hari kehancuran, hari kebangkitan kembali, hari perhitungan, serta hari pembalasan. Ciriciri manusia yang beriman kepada hari akhir, mereka senantiasa beramal sholeh untuk keselamatan di hari akhir kelak. (Syafe'I, dkk, 2014: 104-105). "Dan mereka yang beriman kepada Kitab (Al Quran) yang telah diturunkan kepadamu dan Kitab-kitab yang telah diturunkan sebelummu, serta mereka yakin akan adanya (kehidupan) akhirat” (Q.S Al-Baqarah ayat 4).

Setelah alam semesta seluruhnya hancur, kemudian Allah SWT., membangkitkan kembali seluruh umat manusia untuk diadili di hadapan-Nya tentang semua amal perbuatan yang telah dilakukannya. Pada saat itu tidak seorang pun yang dapat sembunyi atau 
disembunyikan mempertanggungjawabkan seluruh perbuatan masingmasing. Di sini seorang tidak dapat menolong saudara atau teman kerabatnya, kecuali amal shaleh yang telah diperbuatnya semasa hidupnya (Prahara, 2009: 120).

6. Iman kepada Qadha' dan Qadar

Dalam bahasa yang paling sederhana, qadha' adalah ketetapan dan keputusan Allah sejak zaman Azali, sedangkan Qadar/takdir adalah ketetapan atau ketentuan Allah yang berjalan mengikuti qadha-Nya sesudah zaman Azali, yakni dari awal kehidupan di dunia ini sampai di akhirat nanti. Maka yang terjadi berarti dia itu telah ditakdirkan dan ditentukan qadha-Nya oleh Allah, dan apa yang belum terjadi berarti itu belum di tentukan takdirnya dan qadha'-Nya oleh Allah. (Syafe'I, dkk, 2014: 105-106).

Beriman kepada qadha dan qadar adalah kita yakin dan percaya dengan sepenuhnya bahwa sesuatu yang telah atau sedang maupun yang akan terjadi adalah kehendak dari Allah SWT., sebagaimana firman Allah: "Tidak ada suatu keberatanpun atas Nabi tentang apa yang telah ditetapkan Allah baginya. (Allah telah menetapkan yang demikian) sebagai sunnah-Nya pada nabi-nabi yang telah berlalu dahulu. Dan adalah ketetapan Allah itu suatu ketetapan yang pasti berlaku" (Q.S. AlAhzab,33; 38).

\section{Konsep Novel}

Kata novel berasal dari bahasa latin novellas, yang terbentuk dari kata novus yang berarti "baru". Dikatakan baru karena novel adalah bentuk karya sastra yang datang dari karya sastra lainnya seperti puisi dan drama (Santosa dan Wahyuningtyas, 2010: 46). Dalam Kamus Besar Bahasa Indonesia, novel diartikan sebagai karangan prosa yang panjangyang mengandung rangkaian cerita kehidupan seseorang dengan orang-orang di sekelilingnya dengan menonjolkan watak dan sifat setiap pelaku. Novel diartikan sebagai sebuah karya sastra dalam bentuk prosa, novel adalah karya imajnatif yang mengisahkan sisi utuh problematika kehidupan seseorang atau beberapa orang tokoh, kisah novel berawal dari kemunculan persoalan yang dialami oleh tokoh hingga tahap penyelesaiannya (Kosasih, 2008: 54).

Novel merupakan cerita rekaan yang menyajikan tentang aspek kehidupan manusia yang lebih mendalam yang senantiasa berubahubah dan merupakan kesatuan dinamis yeng bermakna. Kehidupan itu sendiri sebagian besar terdiri atas kenyataan social walaupun juga ada yang meniru dan subjektivitas manusia.

\section{METODE}

Jenis data yang dipergunakan dalam penelitian ini adalah kualitatif dan terbatas pada data tertulis, yang berkaitan dengan nilainilai pendidikan akidah. Mengingat jenis data yang diolah berupa data kualitatif, maka jenis penelitian tersebut bersifat non empirik, artinya 


\section{BESTARI}

Vol. 18, No. 1, 2021

p-ISSN 1907-1337; e-ISSN 2807-6532

peneliti tidak memakai istilah populasi maupun sampel, sebagaimana lazimnya dalam penelitian empirik, kuantitatif dan sejenisnya. karena jenis data yang diolah berupa data kualitatif maka yang dideskripsikan dan dianalisis pun secara kualitatif pula (Bachtiar, 1997: 21).

Melihat dari segi tujuan penelitian, maka jenis penelitian mengenai nilai-nilai pendidikan akidah dalam novel MARS Betapa Berartinya Sosok Ibu dalam Hidupku adalah kepustakaan (library research). Penelitian kepustakaan (library research), yaitu seperti menelusuri karya-karya besar yang ditulis oleh para pakar secara monumental atau menelusuri buku-buku teks yang digunakan dalam pembelajaran, penelitian naratif dalam bahasa, penelitian isi, penelitian fenomenologis, penelitian etnografis, Penelitian studi kasus, dan penelitian deskriptif. Penelitian kepustakaan (library research), yakni penelitian yang dilakukan di kamar kerja atau di ruang perpustakaan di mana peneliti memperoleh data dan informasi ojek telitinya lewat bukubuku atau alat-alat audiovisual lainnya (Semi, 2012: 10).

Metode berarti cara yang dipergunakan seseorang peneliti di dalam usaha memecahkan masalah yang diteliti. Penelitian ini menggunakan metode analisis isi (content analysis). Analisis ini digunakan oleh penulis karena penulis akan "mengungkapkan, memahami dan menangkap karya sastra" (Moleong, 1991: 63), sehingga penelitian ini dilakukan untuk memperoleh nilai-nilai pendidikan akidah dalam novel MARS Betapa Berartinya Sosok Ibu dalam Hidupku yang ditulis oleh Aishworo Ang dan untuk mengetahui Adakah relevansinya dengan pendidikan saat ini.

Sumber data terkait dengan subjek penelitian darimana data diperoleh. Subjek penelitian sastra adalah teks-teks novel, novella, cerita pendek, drama dan puisi (Siswantoro, 2010: 72). Sumber data yang dikumpulkan dalam penelitian ini, bila ditinjau dari sifatnya, dapat dibagi menjadi dua macam, yaitu:

1) Data yang diperoleh dari buku yang diteliti dan dianalisis berupa novel MARS betapa berartinya sosok ibu dalam hidupku karya Aishworo Ang sebagai sumber data primer.

2) Data mengenai objek penelitian yang diperoleh dari buku-buku atau hasil-hasil penelitian orang lain yang relevan serta literatur-literatur lain tentang nilai-nilai pendidikan akidah sebagai data sekunder. Data sekunder dalam penelitian ini berupa buku Materi Pendidikan Agama Islam (Mukniah, 2011), Ilmu pendidikan Islam (Ramayulis, 2012), Pendidikan Agama Islam Berbasis Karakter Perguruan (Imam Syafe'i, dkk, 2014), Pendidikan Agama Islam (Toto Suryana Af dkk), Konsep dan Hikmah Akidah Islam (Muhammad Chirzin, 2004), dan lain sebagainya.

Dalam penelitian ini teknik yang digunakan terkait keabsahan data adalah teknik triangulasi. Triangulasi dalam penelitian kredibilitas diartikan sebagai pengecekan data dari berbagai sumber dengan 
berbagai cara dan berbagai waktu (Sugiyono, 2010:125). Teknik triangulasi dapat dilakukan dengan beberapa cara, diantaranya dengan triangulasi sumber, triangulasi metode, triangulasi penelitian, dan triangulasi teori. Teknik triangulasi yang digunakan dalam penelitian ini adalah triangulasi teori. Triangulasi teori memanfaatkan dua teori atau lebih untuk dipadukan. Data-data yang dikumpulkan melalui teknik simak, pustaka dan catat . Selanjutnya teori- teori tersebut kemudian dipadu padankan untuk mengecek data-data yang telah diperoleh guna dapat dipertanggungjawabkan keabsahannya.

Demi terjaminnya keakuratan data, maka peneliti akan melakukan keabsahan data. Data yang salah, akan menghasilkan penarikan kesimpulan yang salah demikian pula sebaliknya, data yang sah akan menghasilkan kesimpulan hasil penelitian yang benar. Penarikan kesimpulan hanyalah tindakan menentukan keakuratan data primer dengan rujukan kepada konsep tertentu sebagai parameter. Keakuratan data tersebut masih harus di validasi agar diperoleh data yang valid. Untuk memperoleh data keabsahan,data temuan empiris harus diuji lagi agar semakin terpercaya (Siswantoro, 2010: 79).

Analisis dilakukan dengan pemaparan dalam bentuk deskriptif terhadap masing-masing data secara fungsional dan relasional (Siswantoro, 2010: 80). Analisis data adalah proses mengolah, memisahkan, mengelompokkan dan memadukan sejumlah data, yang dikumpulkan secara empiris menjadi sebuah kumpulan informasi ilmiah yang terstruktur dan sistematis yang selanjutnya siap dikemas menjadi laporan hasil penelitian (Mukhtar, 2013: 120).

Analisis data yang digunakan dalam penelitian ini berupa teknik deskripsi, narasi dan analisis. Data-data yang diperoleh dan sudah dikategorikan dalam penelitian ini dianalisis secara intens dengan menggunakan content analysis (analisis isi), yaitu suatu metode yang bisa dimanfaatkan untuk penelitian yang bersifat normatif untuk memperoleh gambaran jelas objek yang diteliti. Seperti yang diungkapkan oleh George dan juga Kraucer yang dikutip oleh Muhajir menyatakan bahwa content analysis kualitatif lebih mampu menyajikan nuansa dan lebih mampu melukiskan prediksi lebih baik (Muhajir, 2000: 69). Dalam menganalisis data yang bersifat kualitatif dengan metode analisis isi (content analysis) diperlukan tahapan-tahapan berikut:

1. Pemprosesan Data

Mencari dengan cara mengumpulkan data yang berkaitan dengan masalah yang sedang dibahas dari berbagai sumber dan dipelajari secara teliti, seluruh data yang sudah terkumpul kemudian satu-satunya diidentifikasikan.

2. Kategorisasi

Kategorisasi adalah data-data yang sudah terkumpul dapat dikelompokkan atas pikiran, pendapat, dan kriteria tertentu yang 


\section{BESTARI}

Vol. 18, No. 1, 2021

p-ISSN 1907-1337; e-ISSN 2807-6532

selanjutnya dikategorisasikan ke dalam isi pembahasan penelitian yang berkaitan.

3. Penafsiran Data

Setelah tersedia data-data lengkap dan kategorisasi telah dilakukan, maka dilakukan analisis atau penafsiran terhadap data yang tersedia dengan menggunakan analisis, yang akhirnya dilakukan penafsiran kesimpulan dari apa yang telah dibahas (Moleong, 2002: 190).

\section{HASIL PENELITIAN dan PEMBAHASAN}

\section{Biografi Pengarang}

Novel ini ditulis oleh seorang pemuda bernama pena Aishworo ang atau yang bernama asli Kusworo. Mahasiswa PAI di Universitas Muhammadiyah tersebut telah melahirkan karya pertamanya berjudul Janji Langit (Aishworo Ang, 2011). Banyak pihak penasaran, siapa sesungguhnya Aishworo yang sebelumnya sama sekali tak dikenal di jagat kepenulisan. Kiprah Aishworo Ang di dunia tulis-menulis novel dalam batas-batas tertentu mirip dengan Andrea Hirata, penulis Laskar Pelangi. Lelaki sederhana lulusan UMY jurusan Pendidikan Agama Islam ini, selain menjadi seorang penulis, sehari-hari juga sebagai seorang pengajar di SMK Muhammadiyah Tepus Gunungkidul. Sampai kini ia juga masih aktif sebagai tukang loper koran, pekerjaan yang sering kali dianggap remeh oleh mayoritas masyarakat. Ia masih menekuni pekerjaannya meloper koran itu, karena menurutnya merupakan pekerjaan yang menyenangkan. Aish menulis novel dengan judul MARS Betapa Berartinya Sosok Ibu dalam Hiduku yang diterbitkan Diva Press. Untuk proses pembuatan novel MARS Betapa Berartinya Sosok Ibu dalam Hiduku ini hanya membutuhkan waktu sekitar 4-5 bulan. Novel Mars inilah yang lantas menarik sebuah rumah produksi untuk mengangkatnya ke layar lebar. Film dari novel tersebut dibintangi para artis tersohor, seperti Kinaryosih, Acha Septriasa dan Jajang C Noor. Kusworo dalam menulis tidak punya target tertentu. Yang penting baginya, menulis bisa menjadikannya senang.

2. Sinopsis Novel "Mars Betapa Berartinya Sosok Ibu dalam Hidupku"

Novel ini menceritakan seorang pemuda yang bernama Ali Harimurti. Ali adalah sarjana syariah dari Universitas Al-Azhar. Lulusan cum laude dan menguasai tiga bahasa asing dengan sangat baik. Saat pulang ke tanah air, tawaran-tawaran menarik dia terima, menjadi dosen di beberapa universitas, penceramah di stasiun televisi, pegawai kantoran, atau pekerjaan bagus lain yang akan menjamin dirinya mendapat gaji besar, fasilitas lengkap, kelas sosial yang tinggi dan lain sebagainya. 
Namun nuraninya berkata lain, sebuah pilihan telah diambilnya. Dia memutuskan untuk menjadi pengajar, berdakwah di sebuah daerah tandus dan terpencil dengan segala keterbelakangan. Tak ada gaji, tanpa fasilitas selain sebuah rumah reot berdinding gedek yang berdiri di ujung dusun. Ali ingin meluruskan akidah, karena di dusun manggasari para penduduknya masih mengikuti ajaran leluhur yang mana ajaran tersebut sudah melenceng dari ajaran islam yang sebenarnya, banyak yang percaya akan mitos dan jatuhnya malah menjadi syirik seperti halnya menaruh sesajen untuk mengusir ruh jahat, meminta dilancarkannya rezeki kepada pohon dan dan lain sebagainya. Ali juga ingin menanamkan arti pentingnya pendidikan pada warga yang tak sedikit tidak bisa baca tulis. Karena banyak nya warga yang menyepelekan pendidikan mereka beranggapan bahwa pendidikan itu tidak terlalu penting Karena adanya orang yang bersekolah tinggi akan tetapi masih sulit untuk mendapatkan pekerjaan.

Akan tetapi tidak bagi seorang ibu bernama Tupon seorang perempuan dusun yang lugu dan buta huruf. Dia ingin menyekolahkan putrinya bernama Sekar Palupi setinggi mungkin, ibunya ingin agar Palupi menjadi anak yang cerdas dan memiliki masa depan lebih baik ketimbang dirinya yang buta huruf dan hanya bekerja sebagai penjual tempe keliling. walaupun Tupon hanyalah seorang penjual tempe keliling, akan tetapi semangat nya untuk menyekolahkan Palupi tidak pernah surut. Tupon dan putrinya menjelang malam selalu melihat langit sebelah barat, menyaksikan kerlap-kerlip bintang, menyaksikan bintang berwarna merah, yang tidak lain adalah planet Mars. Oleh Tupon, bintang merah itu disebut Lintang Lantip.

Tiap kali melongok langit itu, Palupi yang masih kecil selalu merengek minta diajak ke Lintang Lantip. "Aku mau ke Lintang Lantib, Mbok". Setiap kali pula Tupon menjawab, jika Palupi mau ke sana caranya adalah dengan sekolah yang rajin.

Pada akhirnya, keinginan Palupi ke planet Mars tercapai. Bukan benar-benar ke planet merah itu, melainkan menjadi pakar planet Mars. Palupi menjadi astronom bidang planet Mars.

3. Nilai-Nilai Pendidikan Akidah dalam Novel "Mars Betapa Berartinya Sosok Ibu dalam Hidupku"

Dalam cerita "MARS Betapa Berartinya Sosok Ibu dalam Hidupku" ini, dapat diuraikan beberapa nilai-nilai pendidikan akidah yang terdapat di dalamnya, yaitu sebagai berikut:

1. Illahiyat

a. Shiffah

1. Penanaman adanya Allah yang tidak serupa dengan makhluk

Allah itu tidak serupa dengan makhluk Jangan sekali-kali menyamakan Allah dengan makhluk-Nya yang bisa tinggal di suatu tempat. Meminta dan memohon pun hanya kepada Allah saja karena 


\section{BESTARI}

Vol. 18, No. 1, 2021

p-ISSN 1907-1337; e-ISSN 2807-6532

hanya Dialah yang bisa mengabulkan segala sesuatu yang kita inginkan.Sebagaimana dalam kutipan novel ini:

Menurut Ali, arwah orang yang sudah meninggal takkan bisa memberi apa-apa. Salah-salah malah bisa terjerumus dalam kesyirikan. (Aishworo Ang, 2011:189).

Kutipan di atas adalah sekilas ingatan Tupon tentang berziarah ke kuburuan, yang mana sebelum ada Ali di Dusun Manggarsari, setiap datang ke makan Ibunya Tupon selalu meminta dimudahkan dalam mencari rizkinya, akan tetapi setelah Ali datang ke Dusun Manggarsari kebiasaan itu tidak lagi dia lakukan, karena Ali memberitau Tupon bahwa dia hanya boleh meminta kepada Allah saja. "Dan Rabb kalian berfirman, "Berdoalah kepada-Ku, niscaya akan Kuperkenankan bagi kalian. Sesungguhnya orang-orang yang menyombongkan diri dari menyembah-Ku akan masuk ke neraka Jahanam dalam keadaan hina dina" . (Q.S. Gafir, 40: 60).

2. Penanaman adanya Allah Yang Kuasa

Kutipan di bawah ini menunjukan bahwa Allah itu yang menguasai alam semesta: Sampai di sini, orang-orang memaknainya sebagai suatu hal yang biasa saja. Tidak ada yang berbeda namun detik berikutnya, dengan gamblang membuktikan bahwa nasib itu sungguh misterius. Ada banyak hal dalam hidup ini yang tidak kita pikirkan terjadi secara tiba-tiba. Bagian atas bukit kapur runtuh, menerjang apapun yang ada di bawahnya, tak terkecuali para penambang yang malang (Aishworo Ang, 2011: 181).

Kutipan tersebut menggambarkan bahwa Allah bisa melakukan apa saja yang Dia inginkan, walaupun tidak pernah diduga-duga oleh akal manusia. Maka dari itu Allah itu Maha Kuasa, Dia yang menguasai Alam ini, apa yang Dia inginkan bisa terjadi dalam sekejap mata, apapun itu baik yang masuk akal maupun yang tidak.

Iman kepada Allah fakta-fakta yang membuktikan adanya Allah SWT Dzat yang maha kuasa sudah cukup banyak diungkapkan baik oleh masyarakat muslim maupun non-muslim akan tetapi jalan pikiran mereka untuk mengenal hakikat yang sebenarnya masih berbeda-beda menurut cara dan konsep mereka sendiri Oleh karena itu sangatlah perlu bagi kita untuk mengetahui sifat-sifat Allah SWT supaya jangan kita keliru untuk menentukan siapa dan bagaimana Allah Yang Maha Kuasa itu (Mukni'ah, 2011: 56).

b. Af'al

Afal adalah perbuatan Allah, dan segala sesuatu, yang ada di dunia ini adalah af'al Allah, termasuk manusia dan semua hal-hal yang terjadi di dunia ini adalah afal Allah. "Dan sesungguhnya telah Kami ciptakan langit dan bumi dan apa yang ada antara keduanya dalam enam hari) pada permulaannya adalah hari Ahad dan selesai pada hari Jumat (dan Kami sedikit pun tidak ditimpa keletihan) kepayahan. (Q.S. Qaf, 50: 38). 
Terdapat perbedaan pendapat dikalangan teolog mengenai perbuatan Tuhan. Ada yang beranggapan bahwa Tuhan dapat berbuat apa saja yang dikehendaki-Nya. Ia dapat memberikan siksa kepada orang yang berbuat baik, dan memberikan pahala kepada orang yang berbuat buruk, jika dikehendakinya. Dengan demikian, Tuhan mempunyai kekuasaan dan kehendak mutlak, sehingga dia tidak tunduk kepada siapapun. Di atas Tuhan tidak ada siapa pun yang dapat menentukan apa yang boleh diperbuat Tuhan atau tidak. Pendapat lain mengatakan bahwa kekuasaan dan kehendak Tuhan tidaklah mutlak semutlak-mutlaknya. Kekuasaan mutlak Tuhan telah dibatasi oleh kebebasan yang diberikan-Nya kepada manusia dalam menentukan kehendak dan perbuatannya (Prahara, 2009: 169).

Adapun kutipan dalam novel "MARS Betapa Berartinya Sosok Ibu dalam Hidupku" yang menggambarkan akidah kepada afal Allah adalah:

1. Membiasakan bersyukur kepada Allah

Adapun dalam novel yang terdapat hal tersebut adalah :

Palupi mengangguk. Siang itu, lahap sekali makannya. Tupon tersenyum melihat putrinya makan dengan begitu lahap. Sebenarnya Tupon cukup lapar, tapi dia memilih tidak ikut makan siang. Dia tak ingin jatah makan anaknya berkurang hingga tak bisa kenyang. Biarlah dirinya nanti makan di rumah saja. Makan Nasi thiwul dan tempe goreng. Tak lebih. (Aishworo Ang, 2011: 152).

Kutipan di atas dapat diambil pelajaran bahwa bersyukur merupakan salah satu wujud terima kasih kepada Allah atas segala nikmat yang telah diberikan. Dan Allah akan menambah nikmat kepada orang yang senantiasa selalu bersyukur.

2. Beribadah

Salah satu beribadah kepada Allah adalah shalat, awal shalat ditandai dengan berkumandangnya adzan. Menunaikan shalat tepat waktu dapat melatih diri kita untuk bersikap disiplin, apabila kita mulai dari disiplin shalat, maka akan terbiasa juga dalam melakukan kegiatan lainnya. Shalat tepat waktu bisa menjadi ukuran disiplin bagi seorang muslim. Adapun kutipan di dalam novel tentang menyegerakan shalat sebagai berikut:

Suara adzan terdengar sayup-sayup beradu dengan suara mesin dan klakson-klakson yang begitu ribut.

"sudah adzan mbok"

"Iya, nduk, kita shalat dulu"

"ke masjid sana, mbok" (Aishworo Ang, 2011: 296).

Kutipan di atas menceritakan tentang perjalanan Tupon dan Palupi yang sedang mencari saudara mereka di Yogyakarta, ketika mereka sedang berjalan terdengarlah suara adzan, Palupi memberitahu Tupon bahwasanya adzan sudah berkumandang, dan Tupon mengajak Palupi untuk shalat terlebih dahulu, sebelum kembali melanjutkan pencarian mereka. 


\section{BESTARI}

Vol. 18, No. 1, 2021

p-ISSN 1907-1337; e-ISSN 2807-6532

Hal yang dapat kita ambil pelajarannya dari kutipan di atas, bahwa dalam keadaan apapun, sekalipun itu mendesak Tupon dan Palupi membiasakan diri untuk menyegerakan shalat. Karena dengan menyegerakan shalat itulah hati kita bisa menjadi lebih tenang dan tidak melakukan segala sesuatunya dengan terburu-buru.

3. Membiasakan diri untuk berdoa dengan sungguh-sungguh

Doa merupakan ungkapan rasa ketidak berdayaan seorang hamba dihadapan Allah dan dengan berdoa berarti kita lebih mendekatkan diri kepada Allah. Hanya kepada Dia-lah kita menyembah dan hanya Dia-lah yang mampu dilakukan oleh manusia. Adapun di dalam novel terdapat cuplikan yang menggambarkan berdoa dengan sungguh-sungguh:

waktu menggantung di pukul tiga sore. Tupon dan Palupi tetap bertahan di sana sambil terus berdoa pada Gusti Allah supaya Surib bisa selamat. Tak berselang lama, terdengar teriakan sambungmenyambung dari para penggali reruntuhan batu (Aishworo ang, 2011: 183).

Pada kutipan di atas menggambarkan bahwa memohon pertolongan hanya kepada Allah semata. Dia yakin tempat kembali manusia itu hanya kepada Allah dan dengan berdoalah kita berusaha untuk bisa menyatu dengan-Nya. Kita juga bisa mengantarkan doa untuk orang-orang yang sudah tiada, agar mereka bisa tenang dan dimudahkan di alam sana.

2. Nubuwat

a. Rasul

Beriman kepada Rasul adalah termasuk bentuk keyakinan kepada Allah bahwa Allah mengutus Rasul dan percaya bahwa Rasul itu ada. Adapun jumlah Rasul yang telah diutus Allah dan disebutkan dalam alQur'an berjumlah 25 Rasul. Selain mempercayai bahwa Allah mengutus Rasul dan Rasul itu ada, termasuk di dalamnya adalah percaya dan menjalankan peraturan dan sunah Rasul yang telah ada dalam hadis. Meneladani seperti yang Rasul lakukan termasuk nilai pendidikan akidah yang menunjukkan nilai nubuwat. "Sesungguhnya telah ada pada (diri) Rasulullah itu suri teladan yang baik bagimu (yaitu) bagi orang yang mengharap (rahmat) Allah dan (kedatangan) hari kiamat dan dia banyak menyebut Allah. (Q.S. Al-Ahzab, 33: 21).

Adapun dalam kutipan novel MARS Betapa Berartinya Sosok Ibu dalam Hidupku adalah sebagai berikut:

Namun nuraninya berkata lain sebuah pilihan telah diambilnya. Dia memutuskan untuk menjadi pengajar, berdakwah di sebuah daerah tandus dan terpencil dengan segala keterbelakangan. Tak ada gaji, tanpa fasilitas selain sebuah rumah reot berdinding gedek yang berdiri di ujung dusun. Sebuah pilihan yang takkan pernah diambil oleh seorang pemuda cerdas dan punya jalan lapang untuk merajut masa depan yang gemilang (Aishworo Ang, 2011: 59). 
Kutipan tersebut menggambarkan seorang pemuda berumur dua puluh lima tahun yang bernama Ali Harimurti, dia adalah sarjana syariah dari Universitas Al-Azhar. Lulusan cum laude dan menguasai tiga bahsaa asing dengan sangat baik, saat pulang ke tanah air, tawarantawaran menarik dia terima. Menjadi dosen di beberapa Universitas, penceramah di stasiun televisi, pegawai kantoran atau pekerjaan bagus lainnya. Akan tetapi, Ali lebih memilih mengabdikan dirinya di Dusun Maggarsari, yang mana dia tidak mendapatkan gaji. Sikap Ali ini mengingatkan kita kepada Rasul dimana Rasul terus berdakwah, selalu menyiarkan Islam dalam kondisi apapun.

Dalam kutipan lain, Ali seseorang yang ingin meluruskan ajaran yang sudah melenceng tersebut memanfaatkan segala sesuatu dengan sebai-baiknya, seperti halnya kutipan di bawah ini:

Dalam batas-batas tertentu, memimpin ritual munggah molo malah dianggapnya sebagai sebuah kesmpatan untuk meluruskan halhal yang selama ini telah salah kaprah di masyarakat (Aishworo Ang, 2011: 65).

Kutipan tersebut menggambarkan bahwa Ali Harimurti ingin mengajak kepada para penduduk dusun manggarsari untuk mengaji alQur'an. Meluruskan akidah serta menanamkan arti penting pendidikan pada warga yang tak sedikit tidak bisa baca tulis. dari hal tersebut kita mengetahui bahwa ada ajakan sikap spiritual kita kepada Allah, mengajak kepada kebaikan juga telah diperintahkan oleh Allah dan telah dilakukan oleh nabi Muhammad. Kutipan lain ketika Ali Harimurti menjalankan tugasnya dengan menyampaikan pentingnya belajar dan mencari ilmu sebagaimana yang diperintahkan Allah dan dijalankan oleh nabi Muhammad:

"Ibu, Bapak sekalian, yang pertama kali diperintahkan oleh Gusti Allah pada manusia adalah iqra', membaca mencari ilmu" (Aishworo Ang, 2011: 60).

Apa yang disampaikan Ali adalah satu fakta yang banyak dilupakan umat Islam hampir disegala bidang kehidupan. Umat islam sepertinya belum sadar juga sikap umat Islam yang malas-malasan telah menjadi kabut tebal yang menutupi kebesaran Islam itu sendiri.

b. Kitab

Kitab yang diturunkan Allah ke dunia ini kepada Rasul ada empat kitab suci, adapun salah satu kitab yang diturunkan Allah kepada Rasulnya adalah kitab alQur'an yang diturunkan kepada Nabi Muhammad saw. Selain beriman kepada Allah dan Rasul seseorang muslim yang diwajibkan beriman kepada kitab Allah, yang mana dalam hal ini adalah kitab al-Qur'an. Adapun cara mengimaninya adalah percaya dan mengerjakan perintah yang ada di dalam al-Qur'an. "Kitab (al-Qur'an) ini tidak ada keraguan padanya; petunjuk bagi mereka yang bertakwa, (Q.S. Al-Baqarah, 2: 2).

Al-Qur'an merupakan intisari dan sumber pokok dari ajaran Islam yang disampaikan Nabi Muhammad SAW kepada umat. Tugas 


\section{BESTARI}

Vol. 18, No. 1, 2021

p-ISSN 1907-1337; e-ISSN 2807-6532

Muhammad selain mengajarkan tauhid juga mengajarkan al-Qur'an kepada umatnya agar secara utuh dan sempurna menjadi milik umatnya yang selanjutnya akan menjadi warisan secara turun temurun, dan menjadi pegangan dan pedoman hidup bagi kaum muslimin sepanjang jalan (Syukur, 2012: 22).

Di dalam novel MARS Betapa Berartinya Sosok Ibu dalam Hidupku yang menunjukkan beriman kepada kitab Allah adalah sebagai berikut:

Ali Harimurti begitu semangat menjalankan tugasnya. Tugas yang didasari panggilan langit untuk mengajarkan mengaji al-Qur'an kepada para warga. Dalam setiap kesempatan mengaji bersama warga yang hanya beberapa gelintir orang. Ali selalu meminta mereka untuk tekun belajar (Aishworo Ang, 2011: 60).

Dari kutipan di atas menunjukan bahwa masih ada segelintir orang yang mau dibimbing untuk mengaji al-Qur'an kitab suci yang diturunkan kepada Nabi Muhammad. Hal itu menunjukkan keimanan segelintir warga yang telah beragama Islam kepada kitab Allah dengan cara membaca dan mengaji al-Qur'an. Dengan demikian kutipan di atas menunjukkan adanya nilai akidah kepada kitab Allah. Allah memerintahkan kepada manusia untuk belajar membaca al-Qur'an dengan melalui perantara kalam yakni membaca dan menulis.

Seperti apa yang Ali sampaikan kepada warga yang ikut mengaji bersamanya untuk mau menyekolahkan anak-anak mereka, Ali berusaha keras meyakinkan mereka bahwa warisan terbaik untuk putraputri mereka adalah ilmu pendidikan. Karena dengan ilmu kita bisa mendapatkan apa yang diinginkan

\section{Ruhaniyat}

Pembahasan mengenai ruhaniyat tidak jauh berhubungan dengan alam metafisik atau alam gaib. Nilai pendidikan akidah di dalam ruhaniyat ini yaitu penanaman keyakinan adanya alam gaib. Memang tentang alam gaib itu seperti tidak masuk akal, atau boleh dikatakan keberadaan alam gaib sesuatu yang tidak nyata. Menurut pandangan mata secara langsung alam gaib tidak terlihat, dan memang tidak nyata adanya. Berikut ini kutipan novel yang menggambarkan adanya alam gaib:

Masyarakat setempat mempercayai kalau pohon itu angker dan merupakan tempat tinggal sing mbaurekso dusun di sekitar telaga (Aishworo Ang: 2011: 14).

Kutipan di atas adalah salah satu ciri penduduk manggarsari yang percaya akan hal ghaib, yang di maksud pohon itu adalah sebuah pohon beringinn yang besar dan tua, mereka mempercayai bahwa biasanya arwah seseorang yang sewaktu hidupnya terkenal sebagai orang sakti dipercayai menjaga suatu tempat. Kutipan berikut ini juga menggambarkan adanya alam gaib yang akan mereka hadirkan. Namun demikian itu adalah hal yang tidak boleh dilakukan, menyembah atau 
memohon kepada sesuatu yang gaib karena hukumnya itu haram sama seperti menyekutukan Allah.

Namun, ternyata benar adanya bahwa alam gaib itu ada. Sebagai manusia yang memiliki keyakinan agama yang dianutnya, bahwa Allah itu menciptakan sesuatu adalah nyata, dan tidak pernah sesuatu itu diciptakan-Nya tersembunyi atau disembunyikan. Semua selalu diperlihatkan kepada manusia. Allah menciptakan manusia dalam keadaan yang sempurna, yaitu manusia diberikan akal, pikiran serta kecerdasan. Dengan modal itulah manusia diberikan kebebasan untuk mencari dan mengungkap segala rahasia Allah yang benar adanya dan nyata. Dalam konteks ini diarahkan bahwa boleh mempercayai adanya alam ghaib, akan tetapi tidak boleh untuk meminta dan menyembah kepadanya.

\section{Sam’iyyat}

Membahas tentang sam'iyyat tidak jauh berhubungan dengan alam barzah atau alam kubur,dan akhirat, kehidupan yang kekal yang pasti akan dialami oleh manusia.

a. Mengingat akan kematian

Jodoh, rezeki, dan mati adalah rahasia Allah SWT yang tidak mungkin diketahui oleh manusia yang lemah. Apa pun yang kita rencanakan, jika sudah tertulis dalam takdir, tidak ada manusia yang kuasa menolaknya. dalam kutipan Novel ini :

"bapakmu sekarang lagi berjalan jauh, nduk. Jauh sekali, menghadap Gusti Allah "jawab Tupon. Orang Jawa meyakini bahwa kematian bukanlah akhir dari kehidupan, oleh karenanya, mereka tak pernah menyebut kematian sebagai lawan dari kehidupan. Kematian bagi orang jawa, adalah sebuah awal dari perjalanan panjang menuju kehidupan yang abadi. (Aishworo Ang, 2011:188).

Kutipan di atas menceritakan tentang Palupi yang menanyakan keberadaan bapaknya kepada Tupon, kutipan tersebut juga menjelaskan bahwa kematian bukanlah akhir dari kehidupan, ketika kita telah tiada di bumi bukan berarti kehidupan kita berhenti sampai di sana saja. Setelah mati kita juga akan menjalankan kehidupan lain di alam sana. Maka dari itu kita senantiasa harus selalu mengingat bahwa kita tidak akan selamanya hidup di dunia, karenakematian tidak bisa kita hindari.

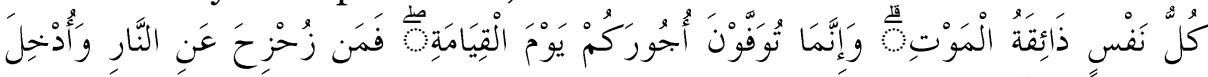



Artinya: Tiap-tiap yang berjiwa akan merasakan mati. Dan sesungguhnya pada hari kiamat sajalah disempurnakan pahalamu. Barangsiapa dijauhkan dari neraka dan dimasukkan ke dalam surga, maka sungguh ia telah beruntung. Kehidupan dunia itu tidak lain hanyalah kesenangan yang memperdayakan. (Q.S. Al-Imran, 3: 185).

Mengingat mati akan melembutkan hati dan menghancurkan ketamakan pada dunia. Tetapi kita tidak diperbolehkan memohon kepada orang yang sudah mati, kalau mendoakan orang yang sudah 


\section{BESTARI}

Vol. 18, No. 1, 2021

p-ISSN 1907-1337; e-ISSN 2807-6532

mati boleh dilakukan. Hidup di dunia ini tidaklah selamanya, akan datang masanya berpisah dengan dunia serta seisinya. Perpisahan terjadi saat kematian menjemput, tanpa ada seorang pun yang dapat menghindar darinya.

b. Penanaman keyakinan adanya takdir Allah

Takdir ada dua macam yaitu takdir mubram dan takdir muallaq. Kutipan novel berikut ini merupakan takdir muallaq dimana ketentuan Allah yang mengikut sertakan peran manusia melalui usaha atau ikhtiarnya. Manusia diberi peran untuk berusaha, hasil akhirnya akan ditentukan oleh Allah.

Namun, Tupon adalah perempuan berhati karang. Semangatnya tak akan terkikis walau deburan ombak masalah terus menderu. Dia sepenuhnya sadar jika dalam kehidupan, banyak hal berjalan tidak sesuai yang dicita-citakan, dia percaya di balik berliku-likunya hidupnya, ada beruntai-untai kebaikan yang disediakan Gusti Allah. Dia telah memutuskan harus tetap berjalan. Seberat apapun itu (Aishworo Ang, 2011: 184).

Kutipan di atas menceritakan tentang Tupon yang telah ditinggal mati suaminya yang bernama Surib, dia begitu gamang memikirkan masalah sekolah putrinya, akan tetapi karena Tupon adalah perempuan yang tangguh, dia akan terus berusaha keras untuk terus menyekolahkan putrinya sampai setinggi mungkin. Takdir Allah itu indah, kita tidak bisa menduga-duga apa yang akan terjadi kepada kita dimasa yang akan datang seperti kutipan di bawah ini:

Ali memang tak pernah bertemu dengan satu pun warga sana. Dan hari ini, secara tiba-tiba salah satu warganya mengunjungi rumahnya dengan cara yang tak pernah dibayangkan sebelumnya. Dia meyakini dompet istrinya yang hilang itu adalah sebuah jalan yang dibentangkan Gusti Allah untuk mempertemukan mereka (Aishworo Ang, 2011: 315).

Kutipan di atas menggambarkan bahwa segala sesuatu dapat dimudahkan oleh Allah. Asal kita mau berusaha keras untuk mau mencapainya. Kutipan di atas menceritakan Ali yang tidak menyangka bisa bertemu kembali dengan warga Dusun Manggarsari setelah dirinya diusir dari Dusun tersebut. Dia bertemu lagi dengan Tupon dan Palupi dari perantara dompet istrinya. Takdir yang membawa mereka akhirnya bisa bertemu lagi setelah sekian lama tak bertemu.

\section{Relevansi Nilai-Nilai Pendidikan Akidah dalam Novel}

Pendidikan akidah memiliki andil yang sangat besar dan penting di dalam kehidupan karena akidah merupakan pokok utama dalam ajaran Islam. Akidah itu diletakkan pertama kali karena memang kedudukannya yang sangat penting dalam ajaran Isalm, seandainya Islam diumpamakan pohon, maka akidah adalah akarnya, dan pohon tanpa akar tentu akan tumbang (Alim, 2006: 122). "Tidakkah kamu perhatikan bagaimana Allah telah membuat perumpamaan kalimat yang 
baik seperti pohon yang baik, akarnya teguh dan cabangnya (menjulang) ke langit. (Q.S. Ibrahim, 14: 24).

Dengan begitu penddikan akidah ini perlu diciptakan dan direalisasikan bagi semua orang. Hal ini menyangkut juga dengan masa depan bangsa. Pendidikan akidah ini merupakan peningkatan keimanan yang dapat membentuk moral (akhlak) sehingga bisa mengendalikan tingkah laku dan perbuatan. Sedangkan moral ini mempunyai arti yang sangat signifikan bagi kehidupan manusia. Tanpa moral yang baik kehidupan masyarakat menjadi tidak tertib, bahkan akan menimbulkan kemiskinan rohani yang dapat menghilangkan nilai-nilai kemanusiaan dalam jiwa seseorang.

Sebelum penulis mengungkapkan relevansi nilai-nilai pendidikan akidah dalam novel "MARS Betapa Berartinya Sosok Ibu dalam Hidupku" dan pendidikan saat ini, penulis akan menjabarkan dulu tujuan pendidikan saat ini yaitu:

1) Dalam UU No. 20 Tahun 2003 tentang sistem Pendidikan Nasional bab II, pasal 3 dirumuskan, pendidikan nasional bertujuan untuk mengembangkan potensi peserta didik agar menjadi manusia yang beriman dan bertakwa kepada Tuhan Yang Maha Esa, berakhlak mulia, sehat, berilmu, cakap, kreatif, mandiri, dan menjadi warga Negara yang demokratis serta bertanggung jawab.

2) Tujuan pendidikan agama di Indonesia adalah untuk memperkuat iman dan ketaqwaan terhadap Tuhan Yang Maha Esa sesuai dengan agama yang dianut oleh peserta didik yang bersangkutan dengan mempertimbangkan tuntutan untuk menghormati agama lain dalam hubungan kerukunan antar umat beragama dalam masyarakat untuk mewujudkan persatuan nasional (Prahara, 2009: 13).

1. Iman Kepada Allah

Hal tersebut sejalan dengan pendapat Lidinillah bahwa iman kepada Allah disamping mengakui bahwa Allah itu ada dan Maha Esa, juga perlu mempercayai sifat-sifat kesempurnaan-Nya, Allah mengetahui segalanya, tiada tersembunyi bagi-Nya barang siapapun. Dia Maha Kuasa dan sanggup melaksanakan segala kehendak-Nya dengan tidak dapat dihalangi oleh siapapun dan kekuatan apapun (Lidinillah, 2005:60).

Namun dalam kenyataan sekarang masih banyak dikalangan masyarakat yang masih mempercayai perkara yang mistis seperti akan jimat, makam keramat, benda-benda pusaka. Selain itu tidak sedikit orang ang mengadukan nasibnya ke dukun misalnya untuk berobat, dan meminta keselamatan.

Untuk meluruskan pemahaman akidah seperti itu jelas tidak bisa dirubah sekaligus, maka disini pentingnya peranan pendidikan akidah kepada para regenerasi selanjutnya untuk meluruskan hal tersebut salah satunya yaitu dengan penanaman nilai-nilai keimanan dari sejak kecil kepada anak. 


\section{BESTARI}

Vol. 18, No. 1, 2021

p-ISSN 1907-1337; e-ISSN 2807-6532

Selanjutnya dalam novel MARS Betapa Berartinya Sosok Ibu dalam Hidupku Ini, mengaplikasikan iman kepada Allah digambarkan oleh sosok Ali, yang sangat takwa kepada Allah seperti tidak pernah meninggalkan shalat. "Shalat mengandung makna pembinaan pribadi, yaitu dapat menghindari dari perbuatan dosa dan kemungkaran. Orang yang melakukan shalat hidupnya akan terkontrol dengan baik" (Suryana, tt: 116).

Melihat fakta kejadian sekarang, maraknya kasus kriminalitas seperti pemerkosaan, pencurian, hingga pembunuhan. Bentuk kriminalitas ini merupakan bentuk perbuatan yang keji dan munkar itu disebabkan karena diri lupa terhadap Allah dengan dimulai dari tidak pernah mengingat Allah dan tidak pernah melaksanakn kewajiban shalat yang lima waktu. Shalat merupakan mekanisme untuk membersihkan hati dan mensucikan diri dari kotoran-kotoran dosa dan kecenderungan melakukan perbuatan dosa (Hajjaj, 2011: 245). Shalat ini menunjukan bahwa adanya pengaruh besar yang ditimbulkan shalat yang disertai kekhusyukan di dalamnya mendidik diri dan mengistiqamahkan perilaku karena itu, orang yang shalat dengan benar menghayati dan khusu akan terhindar dari perbuatan dosa dan munkar.

2. Iman Kepada Malaikat

Beriman kepada malaikat berarti kita percaya dengan sepenuhnya bahwa malaikat itu makhluk Allah SWT yang sangat taat untuk melaksanakan perintah perintahnya dia hanya dianugrahi akal tanpa nafsu maka dia tidak banyak kehendak dan tugasnya bersifat khusus dan tanpa henti (Mukni'ah, 2011: 69).

Jika kita meyakini adanya malaikat yang senantiasa mencatat kebaikan dan keburukan manusia setiap saat, yaitu Malaikat Rakib dan Atid, ia akan selalu berhati-hati. Segala perbuatannya akan dicatat dan diminta pertanggungjawabannya pada saatnya nanti.

Melihat fakta kejadian sekarang, maraknya kasus narkoba yang mana dilakukan oleh orang dewasa maupun anak muda, bahkan banyak artis yang terjerat kasus narkoba, padahal mereka itu orang yang dengan mudahnya tersorot oleh media dan banyak memiliki penggemar, harusnya mereka lebih bisa menjaga sikap, karena bisa saja apa yang mereka lakukan bisa ditiru oleh anak muda zaman sekarang. Jika mereka meyakini adanya malaikat mereka tidak akan melakukan perbuatan tersebut karena mereka pasti yakin bahwa setiap gerak gerik mereka tidak hanya bisa di sorot media akan tetapi juga bisa dicatat oleh malaikat.

3. Iman kepada Kitab Allah

Allah menurunkan wahyu-Nya kepada manusia melalui Rasulnya yang tertulis dalam kitab-kitab-Nya. Kitab-kitab Allah berisi informasiinformasi, aturan-aturan, dan hukum-hukum dari Allah bagi manusi. 
Kitab-kitab Allah itu menjadi pedoman hidup manusia di dunia agar hidup manusia teratur, tentram serta bahagia (Suryana, tt: 99).

Namun sekarang ini al-Qur'an semakin ditinggalkan banyak orang yang tidak sempat meluangkan waktu untuk membaca al-Qur'an. Banyak dari mereka yang sibuk dengan urusan duniawi. Seperti halnya lebih suka membaca status di media sosial dan lebih sibuk membaca gosip dan mengomentari dengan kata-kata yang tidak baik, dari pada meluangkan waktunya untuk membaca al-Qur'an. Sehingga al-Qur'an tampaknya hanya menjadi pajangan cantik di rumah (Mukni'ah, 2011: 199). Oleh karena itu dalam mengimani al-Qur'an bukan hanya diyakini dalam hati saja melainkan diaplikasikan.

4. Iman kepada Nabi dan Rasul

Dalam novel "MARS Betapa Berartinya Sosok Ibu dalam Hidupku" ini salah satu wujud keimanan kepada rasul tertanam dalam sikap Ali yang bisa mencontoh perilaku rasul. Beriman kepada Nabi Muhammad bukan hanya diyakini dalam hati dan diucapkan dengan lisan saja melainkan diaplikasikan dalam kehidupan sehari-hari. Salah satu pengaplikasiannya dengan meneladani sifat-sifat Rasulullah.

Adapun dengan kita beriman kepada para rasul dan nabi Allah diharapkan kita dapat meyakini bahwa para rasul dan nabi itu bisa kita turuti apa-apa yang diperintahkannya dan apa-apa yang dilarangnya sesuai dengan perintah Allah. Kita juga harus meyakini bahwa para rasul itu menerima wahyu yang mengandung petunjuk-petunjuk dan peraturan-peraturan yang dikehendaki oleh Allah agar disampaikan kepada umatnya yang bersangkutan baik itu yang berhubungan dengan keimanan, hukum-hukum, kemasyarakatan dan lain-lain (Mukni'ah, 2011: 73).

Dalam hal ini, banyak orang yang mengetahui sifat-sifat nabi ini namun sedikit yang bisa mengaplikasikannya. Salah satu sifat nabi ini adalah sabar, sabar adalah suatu sikap menahan emosi dan keinginan, serta bertahan dalam situasi sulit dengan tidak mengeluh . Dalam novel ini, sikap sabar selalu tertanam dalam diri Tupon dan Ali, selama hidupnya dia selalu sabar dalam menghadapi cobaan dari Allah SWT.

Rasulullah telah mencontohkan dalam kehidupannya, ia senantiasa bersikap sabar dalam kondisi apapun. Kita sebagai manusia hendaknya bersikap sabar dalam berbagai keadaan. Allah sangat menyayangi dan menjanjikan surga bagi orang-orang yang sabar. Sebagai umatnya, kita wajib mengaku dan mencontoh semua yang ada pada pribadi Rasulullah.

Namun dalam perakteknya di masyarakat banyak orang yang tidak bersikap sabar. Di antara perilaku yang tidak sabar yaitu dapat dibuktikan bahwa sekarang ini banyak sekali yang melakukan maksiat. Misalkan dalam hal pekerjaan banyak orang yang lebih memilih jalan pintas dengan menggunakan cara yang haram seperti halnya mencuri, menjual barang haram dan lain sebagainya. Itu semua dilakukan karena ingin mendapatkan uang dalam jumlah yang banyak dengan cara yang 
mudah. Sedangkan dalam hal penyakit banyak sekarang yang tidak dapat bersabar dalam menghadapi penyakit yang sedang dialaminya, karena merasa tidak kuat dengan rasa sakit itu maka melakukan bunuh diri agar tidak merasakan rasa sakit yang dialaminya lagi.

Hal ini dikarenakan seseorang yang masih belum bisa mengendalikan hawa nafsunya, sehingga tergoda untuk melakukan keburukan. Dengan demikian kesabaran harus menjadi sebuah pembiasaan dalam kehidupan sehari-hari yaitu dengan diimplementasikan dalam setiap kondisi dan situasi.

5. Iman Kepada Hari Akhir

Alam ciptaan Tuhan terikat oleh ruang, waktu serta hukumhukum yang ditetapkan-Nya (sunnatullah). Sesuai dengan hukum tersebut dan dikuatkan dengan pemberitaan dari Allah bahwa dunia akan berakhir pada suatu saat yang disebut hari akhir atau hari kiamat. Pada hari itu alam akan mengalami kehancuran total karena bagaimanapun sesuatu yang dibuat akan mengalami kemusnahan (suryana, $\mathrm{tt}: 101$ ).

Dengan meyakini adanya hari akhir akan membuat seseorang muslim menjadi optimis untuk melakukan hal-hal yang diperintahkan oleh Allah, dan tidak akan pernah menyia-nyiakan waktu sehingga mempergunakan sebaik-baiknya yaitu dengan perbuatan amal shaleh.

Dengan demikian iman kepada hari akhir bukan sekedar diucapkan dalam lisan saja, tetapi diimplementasikan dalam kehidupan sehari-hari yaitu dengan perbuatan amal sholeh. Salah satunya yaitu dengan menghindari sikap cinta terhadap kesenangan dunai, sikap ini tertanam dalam diri Ali yang selalu hidup penuh dengan kesederhanaan, tidak pernah tergoda oleh kesenangan dunia.

Faktanya sekarang, tidak sedikit orang yang terkalahkan oleh hawa nafsunya demi kesenangan dunia. Misalnya, berani mengorbankan kehormatannya demi kekasih yang dicintainya, rela membuka aurat demi mendapatkan pekerjaan yang gajinya lebih besar, berani korupsi karena memperturutkan keinginan untuk lebih kaya lagi dll.

Cinta terhadap kesenangan dunia salah satu jenis penyakit hati. Penyebab manusia bermaksiat, oleh karena itu, keyakinan terhadap hari akhir harus ditanamkan dengan hal-hal yang diperintahkan oleh Allah, dan mempergunakan waktu sebaik-baiknya yaitu dengan perbuatan amal shaleh.

6. Iman Kepada Takdir Allah

Keyakinan terhadap takdir Allah tertanam dalam sikap tokoh yang terdapat dalam novel "MARS Betapa Berartinya Sosok Ibu dalam Hidupku”. Misalnya dengan tokoh yang bernama Ali dan Tupon mereka selalu menyerahkan segala urusannya kepada Allah. Mereka selalu yakin akan takdir Alah, hal ini terbukti dengan keyakinan Ali bahwa usaha nya tidak sia-sia, akan ada cahaya yang berkelip di Manggarsari. Rupanya 
keyakinan itu dibayar lunas oleh Tupon, seorang perempuan buta huruf yang berhasil menyekolahkan anaknya hingga SMA untuk kemudian melanjutkan ke bangku perguruan tinggi (Aishworo Ang, 2011: 317). Dengan demikian beriman kepada takdir Allah berarti meyakini bahwa Allah telah menentukan segala sesuatu yang terjadi kepada makhluknya.

Meskipun segala sesuatu yang ada di dunia ini sudah ada ketetapan atau takdir dari Allah SWT, tetapi kita juga harus mengingat bahwa dalam hidup di dunia ini, Allah menganjurkan kita untuk berusaha, berikhtiar dan berdoa dengan semaksimal mungkin. Sedangkan hasilnya, baru kita serahkan sepenuhnya kepada Allah SWT. Dengan beriman kepada takdir Alah, diharapkan tidak akan cepat putus asa, juga diharapkan akan semakin giat dalam melakukan usaha, ikhtiar yang disertai dengan doa dalam menjalankan setiap usaha kita.

Dengan begitu, beriman kepada takdir akan melahirkan sikap optimisme, tidak mudah kecewa atau putus asa sebab yang menimpa setelah segala usaha dilakukan merupakan takdir Allah. Sesungguhnya Allah akan selalu memberikan yang terbaik sesuai dengan sifat-Nya Yang Maha Pengasih dan Penyayang (Suryana, tt: 103).

Akan tetapi akhir-akhir ini banyak sekali dari manusia yang kadang menyalahkan takdir. Hal ini tentu saja karena mereka tidak mengetahui bagaimana dan apa takdir itu sendiri, meskipun segala sesuatu yang ada di dunia ini sudah ada ketetapan atau takdir dari Allah SWT., tetapi kita juga harus mengingat Allah dalam hidup di dunia ini, Allah menganjurkan kita untuk berusaha, berikhtiar dan berdoa dengan semaksimal mungkin. Sedangkan hasilnya kita serahkan sepenuhnya kepada Allah. Akan tetapi hal ini tidak berarti bahwa kita pasrah begitu saja dengan nasib dan takdir yang ada pada kita tetapi kita juga harus berusaha (Mukni'ah, 2011:78).

Fakta yang ada sekarang, banyak yang membunuh keluarganya sendiri karena faktor ekonomi. Bahkan sampai ada suami yang menjual istrinya sendiri, misalnya saja akhir-akhir ini dikejutkan dengan pembunuhan sadis yang dilakukan oleh seorang suami terhadap istri dan anaknya, hal tersebut di duga karena faktor ekonomi. Pelaku yang merasa putus asa, karena dililit banyak hutang dan juga tidak memiliki pekerjaan nekat membunuh istri dan anaknya.

Hal tersebut berarti bahwa kegagalan, nasib yang "jelek" yang menimpa manusia, mungkin saja bukan merupakan takdir, tetapi hanyalah berupa ujian atau cobaan dari Allah. dalam hal ini, ada kemungkinan bahwa Allah ingin melihat seberapa banyak kita mau untuk berusaha dan berikhtiar. Apakah dengan satu dua kegagalan, kita akan menyerah pada nasib atau kita masih mau berusaha semaksimal mungkin sampai akhirnya memang takdir yang menentukan. Meskipun begitu, kegagalan yang kita peroleh sudah pasti akan selalu mengandung hikmah yang diberikan oleh Allah seandainya kita sendiri yang mau untuk berpikir. Allah tidak mungkin akan melakukan "kejahatan" 


\section{BESTARI}

Vol. 18, No. 1, 2021

p-ISSN 1907-1337; e-ISSN 2807-6532

dengan selalu memberi nasib jelek kepada manusia (Mukni'ah, 2011: 79).

Dengan demikian keyakinan yang kuat kepada takdir Allah harus tertanam pada diri seseorang karena akan melahirkan sikap optimisme dalam menjalani hidup dan tidak mudah putus asa. Namun dalam hal ini, beriman kepada takdir Allah bukan hanya pasrah saja tetapi juga harus didasari dengan ikhtiar dan tawakal, dan apaun hasilnya yang terjadi harus didasari dengan sikap sabar dan rasa syukur agar terhindar dari rasa kecewa juga takabur.

Di sinilah kiranya penulis menganggap bahwa novel ini sangat penting untuk dibaca, memgingat pendidikan akidah yang termaktub di dalamnya itu relevan dengan pendidikan saat ini yaitu pendidikan yang sangat menjunjung tinggi keimanan dan ketakwaan sehingga menghasikan perilaku yang mulia. Maka yang telah digali di dalamnya begitu banyak tuntunan untuk masa sekarang. Bukan hanya saja tuntunan dalam hal penerapan nilai-nilai dan peranannya juga lebih kepada aplikasinya.

\section{SIMPULAN}

Berdasarkan penjelasan yang penyusun paparkan pada bab sebelumnya, maka nilai-nilai pendidikan akidah dalam novel "MARS Betapa Berartinya Sosok Ibu dalam Hidupku" dapat diambil kesimpulan sebagai berikut: (1) Nilai-nilai pendidikan akidah dalam novel "MARS Betapa Berartinya Sosok Ibu dalam Hidupku" ini di antaranya: a) Illahiyat, (masalah ketuhanan seperti tentang Dzat-Nya) Illahiyat adalah nilai-nilai yang membahas tentang segala sesuatu yang berhubungan dengan Illah (Allah), seperti wujud Allah, sifat-sifat Allah, nama-nama Allah af'al Allah dan lain-lain. b) Nubuwat, (masalah kenabian, kitab suci, dan lain-lain) Nubuwat adalah nilai-nilai yang membahas tentang segala sesuatu yang berhubungan dengan Nabi dan Rasul, termasuk pembahasan tentang kitab-kitab Allah, Mukjizat, keramat dan lain sebagainya. c) Ruhaniyat (masalah ghaib seperti ruh, malaikat, jin dan lain-lain). Ruhaniyat yaitu nilai-nilai yang membahas tentang segala sesuatu yang berhubungan dengan alam metafisik seperti malaikat, jin, iblis, setan, ruh dan lain sebagainya. d) Sam’iyyat (masalah-masalah yang bias diketahui melalui wahyu, seperti barzakh, surga, neraka dan lainlain). Sam'iyyat yaitu pembahasan tentang segala sesuatu yang hanya bisa diketahui lewat sam’i (dalil naqli berupa al-Qur'an dan Sunnah) seperti alam barzakh, akhirat, azab kubur, tanda-tanda kiamat, dan lain sebagainya. (2) Relevansi nilai-nilai pendidikan akidah dalam novel "MARS Betapa Berartinya Sosok Ibu dalam Hidupku" dengan pendidikan saat ini yaitu sesuai dengan tujuan pendidikan yang bertujuan meningkatkan kualitas manusia Indonesia, yaitu manusia yang beriman dan bertakwa kepada Tuhan Yang Maha Esa, hal itu selaras dengan isi 
cerita dalam novel "MARS Betapa Berartinya Sosok Ibu dalam Hidupku" yang secara umum mengandung nilai-nilai Keimanan di antaranya iman kepada Allah, iman kepada kitab Allah, iman kepada Malaikat Allah, iman kepada Nabi, iman kepada hari akhir, dan iman kepada takdir Allah. Maka yang telah digali di dalamnya begitu banyak tuntunan untuk masa sekarang bukan hanya saja tuntunan dalam hal penerapan nilai-nilai dan penanamannya, juga lebih kepada aplikasinya.

\section{DAFTAR PUSTAKA}

Ali, Daud Mohammad. (1998). Pendidikan Agama Islam. Jakarta: PT Raja Grafindo Persada.

Arifin, Muzayyin. (2005). Filsafat Pendidikan Islam. Jakarta: PT Bumi

Aksara

Ang, Aishworo. (2011). MARS Betapa Berartinya Sosok Ibu dalam Hidupku. Yogyakarta: Safirah.

Ash-Shiddieqy, Hasbi Muhammad Teungku. 2009. Sejarah \& Pengantar Ilmu Tauhid/Kalam. Semarang: PT. Pustaka Rizki Putra.

Adam, Muchtar. Tt. Ma'rifatul Malaikat Bersahabat dengan Malaikat. Bandung: Makrifat Media Utama

Bachtiar, Wardi. (1997). Metode Penelitian Ilmu Dakwah. Jakarta: Logos Chirzin, Muhammad. (2004). Konsep dan Hikmah Akidah Islam. Yogyakarta: Pustaka Pelajar Offset.

Ilyas, Yunahar. (2009). Kuliah Akidah Islam. Yogyakarta: Lembaga Pengkajian dan Pengamalan Islam (LPPI).

Mukhtar. (2013). Metode Praktis Penelitian Deskriptif Kualitatif. Jakarta: Referensi (GP Press Group).

Rusn, Ibnu Abidin. (2009). Pemikiran Al-Ghazali Tentang Pendidikan. Yogyakarta: Pustaka Pelajar

Rohmat. (2016). Memelihara Kualitas Proses Belajar Mengajar Berbasis Media. Yogyakarta: Gerbang Media Aksara

Sabiq, Sayyid. (1995). Akidah Islam (Ilmu Tauhid). Bandung: CV Diponegoro.

Syafe'I, Imam, dkk. (2014). Pendidikan Agama Islam Berbasis Karakter Perguruan Tinggi. Jakarta: PT RajaGrafindo Persada.

Suryana Af, Toto dkk. tt. Pendidikan Agama Islam. Bandung: Tiga Mutiara.

Santosa, Heru Wijaya dan Wahyuningtyas, Sri. (2010). Pengantar Apresiasi Prosa. Surakarta: Yuma Pustaka.

Semi, Atar M. (2012). Metode Penelitian Sastra. Bandung: CV Angkasa

Siswantoro. (2010). Metode Penelitian Sastra. Yogyakarta: Penerbit Pustaka Pelajar.

Tafsir, Ahmad. (2007). Ilmu Pendidikan Dalam Persepektif Islam. Bandung: PT Remaja Rosdakarya. 


\section{BESTARI}

Vol. 18, No. 1, 2021

p-ISSN 1907-1337; e-ISSN 2807-6532

Thoha, Chabib dkk. (2004). Metodologi Pengajaran Agama. Yogyakarta: Pustaka Pelajar Offset.

Zuhdi, Masjfuk. (1993). Studi Islam. Jakarta: PT Raja Grafindo Persada. Zakiyah, Yulianti Qiqi dan A. Rusdiana. (2014). Pendidikan Nilai Kajian Teori dan Praktik di Sekolah. Bandung: CV Pustaka Setia. 
